Paediatrica Indonesiana 15:211 - 218. July - August 1975. 211

From the Department of Child Health, University of Airlangga/

Dr. Soetomo Hospital, Surabaya

\title{
Intraperitoneal Fluid Therapy in Children
}

$2 y$

HAROEN NOERASID, PITONO SOEPARTO, BING RUDYANTO, SUGENG SUGIJANTO; ABDUL HAMID and A. SARASWATI

\begin{abstract}
The administration of intraperitoneal fluid to 56 children, with gastroenteritis and dehydration, admitted to the Department of Child Health Dr. Soetomo Hospital, was discilssed.

The authors especially considered the practical aspects and the danger aising from the administration of intraperitoneal fluids.

Although nonc of the patients died, some did show restlessness, meteorism, a raised leucocyle-coint and a small rise in body temperature.

The authors are of the opinion that the administration of intraperitoneal fluids is not free of danger and it should be reserved for emergency situation only.
\end{abstract}

Reqeived 2nd May 1975. 


\section{Introduction}

The administration of fluid to overcome dehydration in children with gastroenterittis is undoubtedly important.

The method of rehydration used is not only dependent on the degree of dehydration, but also on the facilities available and the situation in which the fluid is administered. Two problems are commonly encountered, when attempting to rehydralte children: 1) the lack of trained personnel in remote areas; 2) the reluctance of many parents to allow their chilldren to be admitted to hospital. One way of overcoming these problems that must be consildered, is the use of intraperitoneal fluid administration. This method of rehydration was discussed at the WHO Rehydration Course in Surabayra (Pierce, 1971).

Intraperitoneal fluid administration is not extensively used, despite the fact, that this method has been available for more than 50 years. It was initially described by Blackfan and Maxcy (1918) andi afterwards there have been many other reports, a.o. (Carter, 1953; Huckstep, 1962).

The use of this method in adults is unsatisfactory, because the fluid absorbed is insufricient to replace the fluid-loss through diarrhoea. However in children the situation is different, and the results obtained by this method of rehydration are good (Mahalanabis et al., 1970: Ransome Kuti et al., 1969).

The purpose of this research was to find out how far intraperitoneal fluid administration can be effectively applied to the rehydration of children, and to note any sirdeeffects or complications associated with this method.

\section{Material and methods}

Fifty-silx children, who had been admitted to the Department of Child Health, Dr. Soetomo Hospital with gastroenteritis and moderaite dehy dration, were included in the study. Pativents with associated diseases or severe malnutrition were exluded from the study.

The fluid was administered with a sterile infusion set, which was inserted perpendicularly one or two centimeters below the umbilicus. The fluid given was a mixture of normal saline and $5 \%$ glucose, in a ratio of $2: 1$. This flutid was warmed prior to infusion. The total amount of fluid given was $80 \mathrm{ml} / \mathrm{kg}$ body weight, administered rapidly in two phases, each with the amount of $40 \mathrm{ml} / \mathrm{kg}$ body weight every 4 hours.

With this regime, it was anticipated that the dehydration could be overcome (Pierce, 1973), "maintenance" electrolytes were given orally.

Before and four hours after the administration of fluid, each patient 
was examined and the following data were recorded: body weight, pulse and respiration rate, body temperature, state of consciousness, degree of dehydration, the presence of meteorism, the frequency of diarrhoea and vomiting, and the urine output.

Laboratory tests included: leucocyte counts; serum protein levels (using refractometer), PCV (micromethod), serum electrolytes (flame photometer) and $\mathrm{CO}_{2}$ levelis (Van Slyke Method). These tests were also performed on each patient, 24 hours after the intraperitoneal fluid infusion.

In cases of uncontrolled dehydration or when any compuication arose, intravanous fluid was administered using Ringer's lactate solution or a mixture of normal saline, glucose and sodium bicarbonate.

\section{Results}

Out of the 56 patients included in the study, 36 were males and $20 \mathrm{fe}$ males. The ages of the patients ranged from 2 to 18 months, details of which are recorded in the tables: $1,2,3,4,5$, and 6 below.

$\begin{array}{cc}\text { Age } & \text { Total } \\ 0-5 \text { months } & 8 \\ 6-12 \text { months } & 38 \\ 13-24 \text { months } & 10\end{array}$

Discussion

Ransom Kuti et al, (1969) and Mahalanabis et al. (1970) showed the effectiveness of intraperitoneal fluid replacement in children with moderate and "borderline" severe dehydration. This method of fluid administration is usually effectiive, provided that the fluid-loss through the faeces does not exceed $8 \mathrm{ml} / \mathrm{kg}$ body weight/hour (Mahalanabis et al., 1970).

It has been estimated that a dose of $80 \mathrm{ml} / \mathrm{kg}$ body weight of fluid, administered intraperitoneally, will be absorbed in 4 to 6 hours (Pierce, 1973).

From the 56 patients were found that, at 8 hours after commencing intraperitoneal fluid administration, $89.3 \%$ were fully rehydrated, $7.1 \%$ were still mildly dehydrated, whereas only two patients mequired further infusion.

The first phase of fluid administration in itself, is not sufficient to rehydrate a patient. This can be seen from those patients who showed improvement within 4 hours after commencing intraperitoneal fluid administration. In these cases the rise in body weight after the initial phase of fluid administration, was only $0.6 \%$ (statistically not significant, p> 0.10). However there was a significant rise in body weight, $4.4 \%$ $(\mathrm{p}<0.01)$ after the second phase of fluid administration.

It appears that there were more patients with diarrhoea during the 
first phase of fluid administration compared with the second phase (see table 2). This iss a factor, which cannot be overlooked in explaining the increase in body weight during the second phase of fluid administration. Ransome Kuti et al. (1969) described a similar situation, showed that most of the diarrhoea stopped in 6 hours after the administration of initraperiltoneal fluif itself does not increase the incidence of diarrhoea.

The laboratory findings showed a significant fall in P.C.V. and plasma protein suggesting the presence of fluvid retention. In two patients $(3.6 \%)$ the dehydration was not controlled by intraperitoneal fluid adninistration, it became progressive that is was necessary to give intravenous fluid. It was necessary to delay the second phase of fluid administration with two patients in order to explain why the patients had an acutely distended abdomen, or a significant rise in body temperature (from $37^{\circ} \mathrm{C}$ to $39^{\circ} \mathrm{C}$ ).

Ransome Kuti et al. (1969) reported $14(13.3 \%)$ failures out of 105 patients, who had had intraperitoneal fluid rehydration. In these 14 cases it was necessary to adminuster intravenous fluids. The peritoneai membrane is a non selected membrane and diffusion of electrolytes occurning down the concentraticm gradients (Ransome Kuti et al., 1969).
The results of electrolytes examination in 10 patients revealed that all had isotonic dehydration ( $\mathrm{Na} .=$ $133 \mathrm{mEq} / \mathrm{L}$ ), mild hypokalemia (K $=4.09 \mathrm{mEq} / \mathrm{L})$ and acidosils $\left(\mathrm{CO}_{2}\right.$ $=11.8$ vol. $\%$ ). As can be seen from the $\mathrm{Na}, \mathrm{K}, \mathrm{Cl}$ levels there was no significant overall effect on electrolyte balance before or after the adminisitration of initraperitoneal fluid $(p>0.10)$.

Although the acidosis was not completely reversed; it can be expected that the body itself will resolve this problem. Many other workers are of the opinion that the administration of intraperitoneal fluid is safe in children (Blackfan and Maxcy, 1918; Carter, 1953; Hucksitep, 1962; Ransome Kuti et al., 1969), however Maha lanabils et al. (1970) noted that this is so only if an aseptic technic and sterile fluid is used. There is always a danger of bacterial infection of the peritoneum when using this method.

Significant rises in the leucocyte counts and body temperature after the administration of intraperitoneal fluid, necessitate one to consider the possibility of infection, though it should be realized that these changes may be the result of peritoneal irritation alone.

Mahalanabis et al. (1970) did not repont any caise of discomfort or respinatory disturbance in patients being given intraperitoneal fluids. However Ransome. Kuti et al. 
TABLE 1 : The degree of dehydration

\begin{tabular}{|c|c|c|c|}
\hline $\begin{array}{l}\text { Degree of } \\
\text { Dehydration }\end{array}$ & $\begin{array}{l}\text { Before } \\
\text { infusion }\end{array}$ & $\begin{array}{c}4 \text { hours after } \\
\text { infusian }\end{array}$ & $\begin{array}{l}8 \text { hours after } \\
\text { infusion }\end{array}$ \\
\hline - & - & $15(26.8 \%)$ & $50 \quad(89.3 \%)$ \\
\hline Mild & 一 & $35 \quad(62.5 \%)$ & $4(7.1 \%)$ \\
\hline Moderate & $56(100 \%)$ & $4(7.1 \%)$ & $-(0.0 \%)$ \\
\hline Severe & - & $2(3.6 \%)$ & $4(3.6 \%)$ \\
\hline
\end{tabular}

TABLE 2: Body weight

\begin{tabular}{|c|c|c|c|}
\hline Bhase & 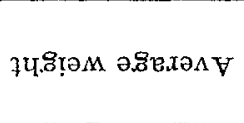 & $\begin{array}{l}\text { Percentage } \\
\text { rise }\end{array}$ & $\begin{array}{l}\text { Signed Ranksum } \\
\text { test of signi- } \\
\text { ficance }\end{array}$ \\
\hline $\begin{array}{l}\text { Before infu- } \\
\text { (O) }(\mathrm{O})\end{array}$ & $\mathrm{X}: 694 \mathrm{gm}$ & - & 一 \\
\hline $\begin{array}{l}4 \text { hours after } \\
\text { infusion (I) }\end{array}$ & $\mathrm{X}: 6985 \mathrm{gm}$ & $0-\mathrm{I} \quad(0.60 \%)$ & $p>0.10$ \\
\hline $\begin{array}{l}8 \text { hours after } \\
\text { infusion (II) }\end{array}$ & $\mathrm{x}: 7170 \mathrm{gm}$ & $0-\mathrm{II}(3.24 \%)$ & $P<0.01$ \\
\hline
\end{tabular}


TARLE 3: Diarrhoea

\begin{tabular}{l|r|r|}
\hline Phase & $I$ & II \\
\hline+ & $32(60.4 \%)$ & $9(17 \%)$ \\
- & $21(39.6 \%)$ & $44(83 \%)$ \\
\hline
\end{tabular}

TABLE 4 : State of Conscionsmess

\begin{tabular}{l|c|c|c}
\hline \multicolumn{1}{|c|}{ Phase } & $\begin{array}{c}\text { Before } \\
(\mathrm{O})\end{array}$ & $\begin{array}{c}4 \text { hours } \\
(\mathrm{I})\end{array}$ & $\begin{array}{c}8 \text { hours } \\
\text { (II) }\end{array}$ \\
\hline Normall & 26 & 23 & 21 \\
Restless & 23 & 32 & 32 \\
Aprathetic & 6 & 1 & 3 \\
Sleepy & 1 & - & - \\
\hline
\end{tabular}


TABLE $5:$ Metoorism

\begin{tabular}{l|c|c|c}
\hline Phase & $\begin{array}{c}\text { Before } \\
\text { (O) }\end{array}$ & $\begin{array}{l}4 \text { rours } \\
\text { (I) }\end{array}$ & $\begin{array}{c}8 \operatorname{cours}_{\text {(II) }} \\
\text { Sensorium }\end{array}$ \\
\hline 5 & 51 & 47 & 97 \\
\hline
\end{tabular}

TABLE 6: Laboratory findings

\begin{tabular}{|c|c|c|c|}
\hline Lab. Exam. & Before & 24 hours & $\begin{array}{c}\text { Signed Ranksum } \\
\text { test of } \\
\text { Significance }\end{array}$ \\
\hline $\begin{array}{l}\text { P.C.V } \\
\text { Plasma protein } \\
\mathrm{Na} \\
\mathrm{Cl} \\
\mathrm{K} \\
\mathrm{CO}_{2} \\
\text { Laucocyte count } \\
\text { Temperature (C) } \\
\text { Pulse rate } \\
\text { Respiration } \\
\text { rate }\end{array}$ & $\begin{array}{c}36.8 \pm 4.20 \\
742 \pm 1.02 \\
133.63 \pm 4.99 \\
102.2 \pm 8.19 \\
4.09 \pm 1.40 \\
11.80 \pm 3.01 \\
8411 \\
37.70 \\
127 \\
40\end{array}$ & $\begin{array}{c}33.4 \pm 3.35 \\
640 \pm 0.99 \\
134.6 \pm 3.63 \\
99.4 \pm 677 \\
3.49 \pm 1.45 \\
13.65 \pm 2.74 \\
11.772 \\
38.20 \\
126 \\
37\end{array}$ & $\begin{array}{c}\mathrm{p}<0.01 \\
\mathrm{p}<0.01 \\
\text { not significant } \\
\text { not significant } \\
\text { not significant } \\
0.01<\mathrm{p}<0.05 \\
\mathrm{p}<0.01 \\
0.01<\mathrm{p}<0.05 \\
\text { not significant } \\
0.01<\mathrm{p}<0.05\end{array}$ \\
\hline
\end{tabular}


(1969) noted that out of 62 of their patients, 10 underwent much discomfort during the fluid administration and another two developed dyspnoea (although this occurred after premedication with promazine).

Many of our patients were irritable and showed signs of meteorism. This was most pronounced during the initial four hours of fluid administration (see table 4 \& 5).
Though many of our patients appeared very pale after receiving the intraperitoneal fluid, their pulse rate remained stable suggesting that the cardiovascular system was not affected. However, we did see obvious dyspnoea in two of our patients. Generally we noted a decreased respiratory rate, which - though small in amount - was significant $(0.01$ $<\mathrm{p}<0.05)$.

\section{REFERENCES}

1. BLACKFAN, K.D. and MAXCY, K.F.: Am. J. Dis. Child. 15 : 19-28 (1918) cited from Mahalanabis et al. (1970),

2. CARTER, F.S.: E. Afr. J. $30: 499-505$ (1953) cited from Mahalanabis et al. (1970)

3. HUCKSTEP, R.L.: Typhoid Fever and other Salmonella infections (Edinburg and London, Livingstone 1962) oited from Mahalanabis et al. (1970).

4. MAHALANABIS, D., SACK, R.B., KAPLAN, J., JACOBS, B., MONDAL,
A : Intraperitoneal fluid therapy in cholera and non cholera liarrhoea. Bull. WHO 42 : 837 (1970).

5. PIERCE, N.F.: Personal communication (1973).

6. RANSOME KUTI, O., ELEBUTE, O., ODUTOLA, T.A., RANSOME KUTT, S.: Intraperitoneal fluid infusion in children with gastroenteritis. Br. med. J. ii : 500 (1969).

7. Rehydration Course W.H.O. - SEARO 0144, 12-16 April 1971, Surabaya. 